\title{
Eesti keele ja matemaatika õppevara valiku põhimõtted ja eesmärgid lasteaia- ja klassiõpetajate hinnangul
}

\author{
Merle Taimalua ${ }^{a}$ Krista Uibua ${ }^{a}$ Heily Leola ${ }^{a^{1}}$ \\ a Tartu Ülikooli haridusteaduste instituut
}

\begin{abstract}
Annotatsioon
Kvaliteetne õppevara on abivahend, mis on õpetajale toeks laste arengu eesmärgipärasel suunamisel. Uurimuse eesmärk oli välja selgitada, millisena hindavad Eesti lasteaia- ja klassiõpetajad oma võimalusi otsustada eesti keele ja matemaatika õppevara valiku üle, millistest põhimõtetest nad lähtuvad ja milliste eesmärkide täitmist õppevara puhul oluliseks peavad. Erinevuste väljaselgitamiseks lasteaia- ja klassiõpetajate hinnangute vahel küsitleti 64 lasteaiaõpetajat ja 47 klassiópetajat, kasutades valikvastuste ja avatud küsimustega ankeeti. Õppevara valiku põhimõtteid analüüsides eristus neli peakategooriat: vastavus õppekavale, sisu ja ülesannete mitmekesisus, sisu ja ülesannete selgus ja arusaadavus, välised tegurid. Õppevara eesmärkidest tõid õpetajad kõige sagedamini välja, et heal tasemel óppevara peaks toetama laste kognitiivsete oskuste kujundamist. Samuti selgus, et võrreldes klassiõpetajatega saavad lasteaiaõpetajad rohkem ise otsustada, millist õppevara eesti keele või matemaatika õpetamisel kasutada. Teadvustades, millistest põhimõtetest õppevara valikul lähtuda ja milliseid eesmärke heal tasemel õppevara täidab, saab õpetaja teha otsuseid, mis toetavad mitmekülgselt lapse arengut.
\end{abstract}

Võtmesõnad: õppevara, lasteaia- ja klassiõpetajad, õppevara valiku põhimõtted ja eesmärgid

\section{Sissejuhatus}

Õppevara puhul peetakse oluliseks, et see toetaks eri eesmärkide saavutamist ning võimaldaks laste kognitiivsete, sotsiaalsete ja metakognitiivsete oskuste arendamist ja õpioskuste rakendamist (Tomlinson \& Masuhara, 2017). Selleks peavad õpetajal olema teadmised, mis iseloomustab head õppevara (Lebeda, Mijoc, \& Tomašević, 2018; Wilkens, 2011), ning oskused, kuidas seda valida. Õppevara kvaliteedi kriteeriumidest on olnud peaasjalikult juttu kooli kontekstis ning eri õppeaineti võivad kriteeriumid erineda. Nii näiteks rõhutatakse inglise keeles keeleliste osaoskuste kujundamist (Miekley, 2005; Tomlinson

Haridusteaduste instituut, Tartu Ülikool, Salme 1a, 50103 Tartu; heily.leola@ut.ee. 
\& Masuhara, 2017), matemaatikas probleemilahendamise oskust (Czeglédy \& Kovács, 2008), keskkonnahariduses tuuakse omaette kriteeriumina välja kultuuriline ja sotsiaalne kontekst (Chou, 2003). Lasteaias räägitakse märksa tagasihoidlikumalt õppevarast, mis on didaktilise eesmärgiga ja välja töötatud õpetamiseks (Hansen \& Gissel, 2017).

Samas on lasteaia roll laste kooliks ettevalmistuses aastatega suurenenud (Bassok, Latham, \& Rorem, 2016; Neudorf, Ugaste, Tuul, \& Mikser, 2017) ning üha rohkem pööratakse tähelepanu õpitegevuste mitmekesisusele, et kujundada laste lugemis- ja kirjaoskust (Leppänen, 2006), arvutamisoskust (Aunio \& Niemivirta, 2010) ja geomeetriliste kujundite tundmist (Resnick, Verdine, Golinkoff, \& Hirsh-Pasek, 2016). Mitmekesiste õppe- ja kasvatustegevuste laiem kasutamine eri valdkondade oskuste ja teadmiste arendamisel (Ugaste, Neudorf, Sarap, Saar, \& Elissaar, 2019) on toonud lasteaias kaasa ka nn kooliliku õppevara - aabitsate, tööraamatute ja -lehtede - ulatuslikuma kasutamise (Bassok et al., 2016). Õppevarana käsitletakse lasteaia kontekstis nii kujundi-, pildi- ja juturaamatuid (Resnick et al., 2016), loov- ja reeglimänge kui ka ümbritsevast keskkonnast pärit esemeid, mis sobivad õppeülesannete täitmiseks (Niikko \& Ugaste, 2012). Tulenevalt materjalide eripalgelisusest, näiteks õppemängud õppimiseks vajalike alusoskuste ning teadmiste kujundamiseks (Ugaste et al., 2019), või lihtsad esemed (riidetükid, kivikesed ja seemned) rühmitamiseks (Palu, 2008), mõistetakse lasteaia õppevara üldisemalt ning selle hindamise kriteeriumidest ei räägita nii nagu koolis.

Sisulised ja tehnilised nõuded, mille alusel hinnatakse Eestis kooli õppekirjandust, on esitatud määruses „Õppekirjandusele esitatavad nõuded, õppekirjanduse retsenseerimisele ja retsensentidele esitatavad miinimumnõuded ning riigi poolt tagatava minimaalse õppekirjanduse liigid klassiti ja õppeaineti“ (2016). Lisaks osutatakse „Põhikooli riiklikus õppekavas“ (2011/2014) õppevara esteetilisele välimusele ning sellele, et kasutada tuleks õppevara, mis on lastele eakohane ja kohandatav nende individuaalsete eripäradega. Samas ei ole õppevara mõistet õppekavas defineeritud ja õppevara liike kirjeldatud. „Koolieelse lasteasutuse riiklikus õppekavas“ (2008) ja kutsestandardis (tase 6) määratletakse lasteaiaõpetaja ülesanded: valida õppevara, arvestades seejuures õpieesmärke ja õppija arengutaset; märgata õppevara puudusi; teha ainevaldkonna juhtidele ettepanekuid õppevara kohandamiseks ja koostamiseks (Kutsestandard, 2020).

Õpetajate otsustusõigust ja vastutust õppevara ja -materjalide kasutusel on uuritud nii rahvusvahelises võrdlusuuringus TALIS (OECD, 2008, 2013, 2018) kui ka Eestis korraldatud uuringutes (Erss, Kalmus, \& Autio, 2016; Tuul, Mikser, Neudorf, \& Ugaste, 2015). TALIS 2018 uuringust selgus, et Eesti kolmanda kooliastme õpetajatel on väga suur otsustusõigus võrreldes teiste 
OECD riikide õpetajatega (Taimalu, Uibu, Luik, Leijen, \& Pedaste, 2020). Suurt valikuvabadust ja -võimalust valida ise õppevara ja teisi metoodilisi materjale soovivad ka lasteaiaõpetajad (Tuul et al., 2015). Põhikooli esimese kooliastme õpetajate otsustusõigust ja võimalusi valida ise õppevara Eestis analüüsitud ei ole. Samas peetakse oluliseks, et lasteaia- ja klassiópetajad teeksid omavahel koostööd (Ahtola et al., 2011) eesmärgiga pakkuda lastele sujuvamat üleminekut lasteaiast kooli. Sarnastest põhimõtetest, eesmärkidest ja arusaamadest lähtumine õppevara koostamisel ja valikul võib seda üleminekut toetada. Siinse uurimuse eesmärk oli välja selgitada, millisena hindavad Eesti lasteaia- ja klassiõpetajad oma võimalusi otsustada eesti keele ja matemaatika õppevara valiku üle, millistest põhimõtetest nad lähtuvad ja milliste eesmärkide täitmist õppevara puhul oluliseks peavad. Lisaks analüüsiti erinevusi laste- ja klassiõpetajate hinnangute ja arvamuste vahel.

\section{Õpetajate otsustusõigus ja põhimõtted õppevara valikul}

Õppetöö eesmärkide täitmiseks ja laste arengu toetamiseks eri tasanditel peab õpetajal olema oskus ja võimalus valida õppevara, mis on lastele eakohane ning arvestab nende eripära (Kutsestandard, 2020; Põhikooli riiklik õppekava 2011/2014). Varasematest uuringutest on selgunud, et õpetajal ei ole alati otsustus- ja valikuvõimalust (Lalau, 2014; Reichenberg \& Andreassen, 2017) ning selle puudumisel tuleb hakkama saada õppeasutuses olemasoleva õppevaraga või koostada see ise (Viirpalu, Krull, \& Mikser, 2014). Õppevara koostamisel on oluline arvestada õppija vajadusi ja vastavust õppekavale (Howard \& Major, 2004). See eeldab õpetajalt eriteadmisi, kuidas õppevara koostada, ja piisaval hulgal aega (Erss et al., 2016; Howard \& Major, 2004; Lopera, 2015).

Õppevara suunab ka metoodilisi valikuid, mida õpetaja õppetöös teeb (Sousa \& Dionisio, 2011). Lasteaias soovitatakse kasutada mängulist õpet (Gustafsson \& Mellgren, 2010; Võgotski, 2016), üldõpetuslikku tööviisi (Koolieelse lasteasutuse riiklik õppekava, 2008) ja valdkondade lõimimist (Kulderknup, 2008), koolis õppijakeskset õpetamist (Kirkgöz, 2009). Hea õppevara peaks olema kooskõlas õpetamisega eri kooliastmetel. Samas on ilmnenud, et lasteaia óppevara ei arvesta piisaval määral laste vanust, näiteks ei sisalda eelkooliealiste laste õppevara küllaldaselt mänge, laule ja salmikesi (Birhan, 2018). Eestis korraldatud Petersoni, Tuule ja Veissoni (2013) uuringust selgus, et lasteaias tuleks rohkem tähelepanu pöörata laste vaba tegevuse vahenditele ja lapsekesksust toetavatele võimalustele rühmas, näiteks muusikavahendite kasutamisele, rollimängu võimalustele, katsete tegemisele.

Õpetaja ülesanne on hinnata õppevara eakohasust õpilasele (Bartan, 2011) ning arvestada seda õppevara koostamisel (Koolieelse lasteasutuse riiklik 
õppekava, 2008; Põhikooli riiklik õppekava 2011/2014). Eakohasus ei tähenda õpetamist üksnes laste vanusest lähtudes, vaid arvestada tuleb samaealiste laste erinevat arengutaset. Seepärast peaks õppevara olema ühtviisi jõukohane nii eakohase arenguga ja nõrgematele lastele (Gürkaynak, 2015) kui pakkuma väljakutset ka andekamatele (Czeglédy \& Kovács, 2008). Hea õppevara ülesehitus peaks järgima põhimõtet, et tekstid, harjutused ja ülesanded oleksid mitmekesised ja neid saaks hõlpsasti diferentseerida (Reints \& Wilkens, 2019). Selleks sobivad erisugused individuaalset (Czeglédy \& Kovács, 2008) ja koostööd võimaldavad tegevused (Kirkgöz, 2009) ning laste loovust arendavad ülesanded (Lebeda et al., 2018). Lisaks toetavad eakohast õpetust õppevara sisu selgus ja arusaadavus (Ho \& Hsu, 2011), õppevara ülesehituse loogika (Czeglédy \& Kovács, 2008; Lebeda et al., 2018) ja tööjuhiste mõistetavus (Howard \& Major, 2004).

Õpetajad peavad oluliseks ka seda, et õppevara moodustaks terviku (Sousa \& Dionisio, 2011). Seetõttu võiksid õppevara juurde kuuluda lisaks õpikule või töövihikule abimaterjalid, näiteks harjutusvihik, töölehed, kontrolltööde kogumik ja õpetajaraamat (Czeglédy \& Kovács, 2008). Kui üldiselt peetakse koolilikku õppimist lasteaias pigem mittesoovitatavaks, siis Nugin (2018) leiab, et töölehti võiks korra nädalas kasutada. Nii õpib laps järgima tööjuhiseid, mis on tähtis oskus lapse hilisemal kooliteel. Abimaterjalid aitavad õpetajal õpetada metoodiliselt korrektselt, kuid väiksema ajakuluga.

Vähetähtsad ei ole ka õppevara välimus ja hind (Reints \& Wilkens, 2019). Tõetruud illustratsioonid täiendavad ja näitlikustavad õpikus esitatud teavet (Birhan, 2015) ja tekste (Lebeda et al., 2018), aidates lastel näitlikustamise teel kergemini mõista uut infot. Õpetajate õppevara valikuid mõjutavad ka varasem kasutuskogemus, kolleegide soovitused ning õppevara maht ja hind (Reichenberg, 2014). Samas, kui valida õppevara hinna järgi, võib selle sisuline kvaliteet tagaplaanile jääda.

\section{Õppevara eesmärgid}

Õpetaja seab õpetamisele eesmärgid ja valib õpetamistegevused, mis aitavad neid eesmärke saavutada (Uibu \& Kikas, 2014). Eesmärke saab jaotada mitmeti, kuid selleks, et lapse oskused igakülgselt areneksid, peavad eesmärgid toetama nii kognitiivsete, afektiivsete kui ka metakognitiivsete oskuste edenemist (Hattie, Biggs, \& Purdie, 1996). Kognitiivsete oskuste kujunemist võimaldavad ülesanded, mis nõuavad lapselt konkreetsete tegevuste rakendamist ning hõlbustavad teadmiste ja oskuste omandamist, näiteks tekstis sisalduva olulise info allajoonimine, märkmete tegemine (Griffith \& Ruan, 2005). Afektiivsed oskused on seotud õppimise selliste aspektidega nagu motivatsioon 
ja eneseteadvus. Metakognitiivsed oskused seostuvad enesereguleeritud õppimisega. Sellesse rühma liigituvad ülesanded, mis on suunatud õppimise kavandamisele, jälgimisele ja elluviimisele ning mis toetuvad teadmisele, millist konkreetset tegevust kus ja kuidas kasutada sobib (Griffith \& Ruan, 2005; Samuels, Ediger, Willcutt, \& Palumbo, 2005). Õppevara on see põhivahend, mis toetab õpetajat eri eesmärkide saavutamisel ja õpilaste oskuste kujundamisel.

Et võimaldada diferentseerimist kognitiivsetel tasemetel, peaksid õppevara tekstid, ülesanded ja harjutused olema mitmekesised (Lopera, 2015; Mikk, 2000). Näiteks et kujundada arusaamist õpitust, peaks õppevara võimaldama erinevate õpetamistehnikate kasutamist (Sousa \& Dionisio, 2011), sealhulgas tekstist kokkuvõtte või ülevaate tegemist ning täpsustavate küsimuste esitamist varem õpitu meenutamiseks (Kärbla, Uibu, \& Männamaa 2017). Samuti peaksid ülesanded pakkuma võimalust erisuguste teadmiste (Nemati, 2009) ja õpistrateegiate rakendamiseks (Lopera, 2015) ning igapäevaeluga seotud probleemide lahendamiseks (Czeglédy \& Kovács, 2008). Analüüsimiseks valitud probleemid peavad olema lastele jõukohased (Reints \& Wilkens, 2019). Päriseluga seostamine muudab situatsiooni lastele realistlikuks, pakub võimalusi arutleda õpitu üle (Czeglédy \& Kovács, 2008; Nemati, 2009) ning arendab oskust teadmisi analüüsida ja süstematiseerida (Fahyuan, Atmazaki, \& Ermanto, 2018). Näiteks lasteaialastel võib lasta mõtelda, kuidas lahendada omavahelisi konflikte verbaalsete suhtlusvahendite abil.

Afektiivsete oskuste kujundamist toetavad õppevara ülesanded peaksid olema suunatud laste emotsionaalsele kohanemisele. Laps vajab afektiivseid oskusi, et keskenduda õppimisele, tulla toime õppeprotsessis tekkivate ebaõnnestumistega (Hattie et al., 1996) ning olla motiveeritud õppima (Fahyuan et al., 2018). Õpimotivatsiooni tekitamist ja hoidmist peetakse olulisimaks afektiivseks eesmärgiks, mida õppevara toetama peab (Reints \& Wilkens, 2019; Tomlinson, 2011). Üheks võimaluseks siin on tekstide ja sõnavara eakohane maht (Braga, 2014) ja ülesannete seostamine laste huvidega (Mikk, 2000). Näiteks kui laps tunneb huvi lennukite vastu, siis tuleks lugema õpetamisel kasutada lennukiteemalisi tekste. Teisalt, huvi tekitamine lugemise vastu (nt mänguliste tegevuste, rollimängude ja diskussiooni kaudu) aitab paranda nii laste sõnavara tundmist kui ka tekstimõistmise oskust (Braga, 2014; Käsper, Uibu, \& Mikk, 2018). Niisiis pakkudes lastele õppevaras ülesandeid, mis toetavad afektiivseid oskusi, paranevad ka nende kognitiivsed oskused.

Peale kognitiivseid ja afektiivseid oskusi arendavate tekstide ja ülesannete peaks õppevara sisaldama ülesandeid, mis toetavad metakognitiivseid oskusi. Need oskused on seotud oma õppimise seiramisega (ingl monitoring) ja seda mõjutavate teguritega. Nii peaksid ülesanded ja harjutused võimaldama lapsel 
oma tegevust hinnata (Howard \& Major, 2004), aidates mõista, kuivõrd otstarbekas on eesmärgi täitmiseks valitud tegevus või mida tuleks järgmisel korral teisiti teha (Chou, 2003). Samuti peab õppevara pakkuma lapsele võimalust õpitut tõlgendada ja teha iseseisvalt järeldusi (Littlejohn, 2011). Selleks sobivad arutelud ja avatud küsimused (Babic \& Baucal, 2011). Kuigi koolieelikute õppevara puhul on keskmes kognitiivsete oskuste arendamine (Sánchez, de la Cal, \& Quintana, 2019), tuleks koolieelses eas teha algust ka metakognitiivsete oskuste kujundamisega, et lapsest kasvaks iseseisev ja ennastjuhtiv õppija. Nii on viie- kuni seitsmeaastaste laste puhul leitud, et metakognitiivsete oskuste arendamine aitab kaasa hilisema õpiedu saavutamisele (Bryce, Whitebread, \& Szücs, 2015).

\section{Eesmärk ja uurimisküsimused}

Õpetaja on see, kes seab laste õppimisele eesmärgid, lähtudes õppekava nõuetest, ning valib eesmärkide täitmiseks sobivad õpetamistegevused ja õppevara. On leitud, et teadlikult ja eesmärgipäraselt valitud õppevara toetab laste õppimist suurel määral (Lebeda et al., 2018; Wilkens, 2011). Uurimuse eesmärk oli välja selgitada, millisena hindavad Eesti lasteaia- ja klassiõpetajad oma võimalusi otsustada eesti keele ja matemaatika õppevara valiku üle, millistest põhimõtetest nad lähtuvad ja milliste eesmärkide täitmist õppevara puhul oluliseks peavad. Eesmärgi täitmiseks analüüsiti erinevusi lasteaia- ja klassiõpetajate hinnangute ja arvamuste vahel, lähtudes kolmest uurimisküsimusest.

1) Kuivõrd saavad lasteaia- ja klassiõpetajad ise otsustada, millist õppevara eesti keele ja matemaatika õpetamisel kasutada?

2) Milliseid põhimõtteid peavad lasteaia- ja klassiõpetajad oluliseks eesti keele ja matemaatika õppevara valikul?

3) Milliseid eesmärke peaks lasteaia- ja klassiõpetajate hinnangul täitma heal tasemel õppevara?

\section{Metoodika}

\section{Valim ja protseduur}

Uuringu valimi moodustamisel arvestati kaht kriteeriumi. Esiteks, uuringusse kaasati õpetajad, kes töötasid koolides ja lasteaedades, mis kuulusid kahe õpetajakoolituse eest vastutava Eesti ülikooli innovatsioonikoolide ja -lasteaedade või praktikabaaside võrgustikku. Teiseks, uuringus osalevalt õpetajalt eeldati põhikooli esimeses kooliastmes või lasteaia koolieelikute rühmas (kuue- kuni seitsmeaastaste laste) õpetamise kogemust. Lasteaedu ja koole, 
kus õpetajad töötasid, oli seitsmest maakonnast, maalt ja linnast, nende hulgas suured ja väikesed koolid ja lasteaiad.

Kutse osaleda uuringus saadeti kõikide innovatsioonikoolide $(\mathrm{N}=32)$ ja lasteaedade $(\mathrm{N}=38)$ juhtidele palvega edastada see oma õppeasutuse kõikidele õpetajatele, kes vastavad uuringu kriteeriumidele. Elektroonilise küsitluse link oli lisatud kutsele. Ankeedile vastas 111 õpetajat, kellest 64 olid lasteaia- ja 47 klassiõpetajad. Õpetajate hulgas oli kaks meest. Lasteaiaõpetajate vanus varieerus $24-68$ aastani $(M=46,7 ; S D=11,4)$ ja klassiõpetajate vanus 23-70 aastani $(\mathrm{M}=44,7 ; \mathrm{SD}=10,4)$. Lasteaia- ja klassiõpetajate rühma vanuse vahel statistiliselt olulisi erinevusi ei olnud $(t=0,96, p=0,34)$. Ka töökogemuse poolest olid õpetajate rühmad sarnased $(t=0,40, p=0,69)$. Lasteaiaõpetajate tööstaaž varieerus 1-46 aastani $(M=19,6 ; S D=13,4)$ ja klassiõpetajate staaž $0-50$ aastani $(M=20,6 ; S D=12,2)$. Ankeedile vastamiseks anti õpetajatele aega üks nädal, seejärel saadeti lasteaedade ja koolide juhtidele uus kiri palvega tuletada õpetajatele meelde ankeedi täitmist.

\section{Mõõtevahend}

Kasutades osaliselt õpetajate õpetamise eesmärkide ja tegevuste uurimise mõõtevahendi väiteid (Uibu \& Kikas, 2014; Uibu, Salo, Ugaste, \& RaskuPuttonen, 2017), koostati siinses uuringus ankeet, millega analüüsiti lasteaia- ja klassiõpetajate otsustusõigust ja -vabadust valida ise õppevara ning olulisemaid põhimõtteid ja eesmärke kahe ainevaldkonna õppevara puhul. Uurimaks, kuivõrd lasteaia- ja klassiõpetajad saavad ise otsustada õpetamisel kasutava õppevara üle, kasutati kolmepalliskaalat („saan täielikult ise otsustada ja valida“; „saan natuke otsustada ja valikul kaasa rääkida“; „ei saa ise otsustada ega valikul kaasa rääkida"). Teiseks paluti õpetajatel nimetada vabas vormis kolm olulisemat põhimõtet, millest nad lähtuvad eesti keele (lasteaias keele ja kõne valdkonna) ja matemaatika õppevara valikul. Kolmandaks küsiti õpetajatelt, milliseid eesmärke peaks täitma heal tasemel õppevara. Selleks kasutati 18 vastusevariandist koosnevat loetelu (Mayer, 2002; Uibu, Mikk, Taimalu, \& Kärbla, avaldamata käsikiri), mille hulgast ópetajad pidid märkima jah-eiskaalal need valikud, mida nad õppevara puhul oluliseks peavad (vt lisa 1).

Uuringu valiidsuse suurendamiseks testiti ankeeti nelja lasteaiaõpetaja ja kolme klassiõpetajaga, kellel paluti täita ankeet ning seejärel küsiti tagasisidet ja ettepanekuid muudatuste tegemiseks. Õpetajate tagasiside põhjal täpsustati ankeedis väidete sõnastust või muudeti neid nii, et ankeet sobiks täitmiseks eraldi lasteaias või koolis (nt kasutades klassiõpetaja ankeedis sõnu eesti keel ja lasteaiaõpetajate ankeedis valdkond „Keel ja kõne“). 


\section{Andmeanalüüsi meetodid ja kirjeldus}

Andmeanalüüsiks kasutati kvantitatiivset sisuanalüüsi (vt Riffe, Lacy, \& Fico, 2005) ja kirjeldavat statistikat. Et leida, millised erinevused avalduvad lasteaiaõpetajate ja klassiõpetajate võimaluste vahel ise õppevara valida, kasutati $\chi^{2}$-ruut-testi. Et võrrelda, milliseid eesmärke peavad õpetajad oluliseks hea õppevara puhul, kasutati mitteparameetrilist Mann-Whitney U-testi. Analüüsimiseks kasutati statistikapaketi SPSS Statistics versiooni 24.0.

Saamaks ülevaadet õppevara valiku põhimõtetest, analüüsiti õpetajate vabavastuseid kvantitatiivse sisuanalüüsi meetodil. Selleks märgiti õpetajate vastustes ära teemakohased andmelõigud (sõnad, fraasid või laused), valides need analüüsiühikuks, ning loodi esmased koodid. Usaldusväärsuse suurendamiseks kodeerisid kaks uurijat teineteisest sõltumatult 14 õpetaja vastuseid (13\%) ja võrdlesid oma tulemusi (vt Bazeley, 2013). Koodide sisuline kooskõla oli $100 \%$, erinevusi kodeerijate vahel esines üksnes koodide sõnastuses. Seejärel liideti sarnase sisuga koodid ja liigitati need alamkategooriatesse (igaühes 1 kuni 8 koodi).

Sisuliste kokkulangevuste põhjal tekkis õppevara valiku põhimõtete kohta neli peakategooriat. Esimesse peakategooriasse „Vastavus õppekavale“ rühmitati kaheksa alamkategooriat. Teise peakategooriasse „Sisu ja ülesannete mitmekesisus“ ning kolmandasse peakategooriasse „Sisu ja ülesannete selgus ja arusaadavus" koondati kummassegi neli alamkategooriat. Neljanda peakategooria „Välised tegurid“ moodustasid viis alamkategooriat. Näide peakategooria „Vastavus õppekavale“ kahe alamkategooria loomisest koos analüüsiühikutega on esitatud joonisel 1 .

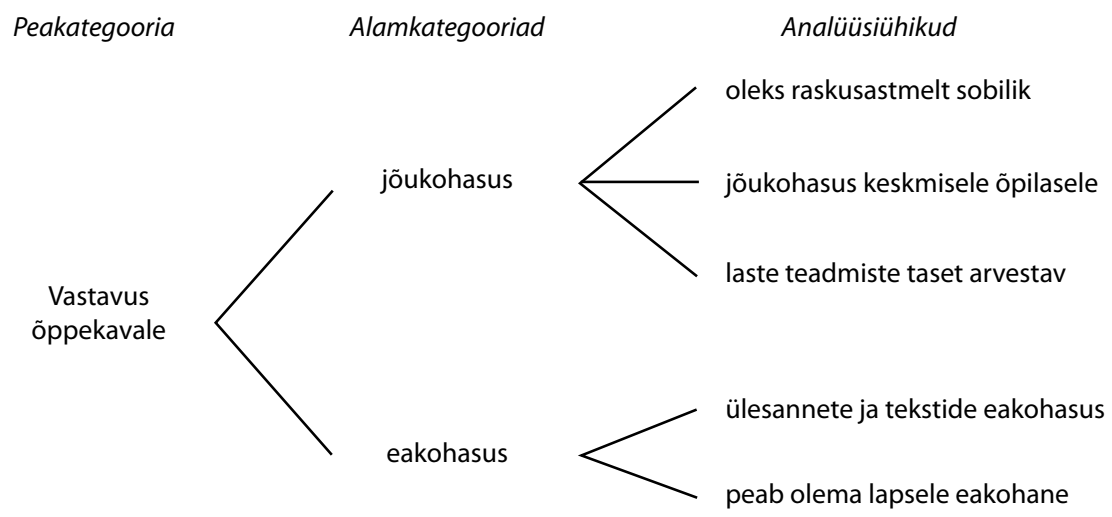

Joonis 1. Näide peakategooria „Vastavus õppekavale“ ja selle kahe alamkategooria loomisest. 
Õppevara eesmärgid jaotati kolme rühma, lähtudes Hattie jt (1996) õpioskuste liigitusest (vt lisa 1). Esimesse rühma „Kognitiivsed eesmärgid“ rühmitati seitse õpieesmärki, mis on suunatud ópilaste kognitiivsete oskuste arendamisele (nt arendada probleemilahendamise oskust). Teise rühma „Afektiivsed eesmärgid“ määrati kuus eesmärki, mis on suunatud emotsionaalse kohanemise oskuste kujunemisele (nt toetada ópimotivatsiooni). Kolmandasse rühma „Metakognitiivsed eesmärgid“ liigitati viis eesmärki, mille sisuks on kujundada oskust seirata oma õppimist ja seda mõjutavaid tegureid (nt jälgida oma tegevust õppimisel). Selle põhjal, mitu eesmärki iga õpetaja loetelust valis, arvutati õpetaja koondmediaanid kõigi kolme eesmärkide rühma kohta.

\section{Tulemused}

\section{Otsustusõigus ja valiku põhimõtted õppevara puhul}

Enamiku lasteaiaõpetajate hinnangul $(92,2 \%)$ on neil täielik õigus ise otsustada, millist õppevara kasutada keele-kõne ja matemaatika valdkonnas. Selliseid õpetajaid, kes ise üldse õppevara valida ei saa, lasteaiaõpetajate hulgas ei olnud. Seevastu sai klassiõpetajatest täielikult otsustada eesti keele ja matemaatika õppevara valiku üle vaid $8,5 \%$ ning $14,9 \%$ tõi välja, et nad ei saa üldse ise õppevara üle otsustada. 76,6\% uuringus osalenud klassiõpetajatest väitis, et saab siiski mingil määral õppevara valikul kaasa rääkida. Erinevusi lasteaiaja klassiõpetajate võimaluste vahel valida õppevara analüüsiti $\chi^{2}$-ruut-testiga. Kahe rühma hinnangute vahel ilmnes statistiliselt oluline erinevus lasteaiaópetajate kasuks $\left(\chi^{2}=74,11, \mathrm{p}<0,001\right)$.

Järgnevalt uuriti, milliseid põhimõtteid peavad lasteaia- ja klassiõpetajad õppevara valikul oluliseks. Selleks paluti õpetajatel nimetada kolm peamist põhimõtet. Õpetajate vastuseid analüüsiti sisuanalüüsi meetodil, liigitades õppevara valiku põhimõtted nelja peakategooriasse (vt tabel 1).

Lasteaiaõpetajad nimetasid klassiõpetajatest mõnevõrra sagedamini õppevara vastavust õppekavale ja ülesannete mitmekesisust. Samas tõid klassiõpetajad harvem välja õppevara välimuse. Järgnevalt antakse ülevaade õpetajate välja toodud põhimõtetest nelja peakategooria kaupa. Tulemused joonistel 2-5 on esitatud lasteaiaõpetajate vastustes avaldunud põhimõtete esinemissageduse järjekorras.

Peakategooriasse „Vastavus õppekavale“ liigitati kaheksa alamkategooriat, mis hõlmavad õppimise üldiseid põhimõtteid lasteaias või koolis (vt joonis 2). Vähemalt mõnda nendest põhimõtetest nimetas 70,3\% lasteaiaõpetajatest ja $53,2 \%$ klassiõpetajatest. 
Tabel 1. Pea- ja alamkategooriad õppevara valiku põhimõtete kohta

\begin{tabular}{llll} 
& \multicolumn{2}{c}{ Peakategooriad } & \\
\hline $\begin{array}{l}\text { Vastavus } \\
\text { Õppekavale }\end{array}$ & $\begin{array}{l}\text { Sisu ja ülesannete } \\
\text { mitmekesisus }\end{array}$ & $\begin{array}{l}\text { Sisu ja ülesannete selgus ja } \\
\text { arusaadavus }\end{array}$ & Välised tegurid \\
& \multicolumn{1}{c}{ Alamkategooriad } & \\
\hline $\begin{array}{l}\text { Eakohasus } \\
\text { Õppekava nõuded } \\
\text { Lõimitus }\end{array}$ & $\begin{array}{l}\text { Mitmekesisus ja erinev } \\
\text { ülesannete valik }\end{array}$ & Arusaadavus & Atraktiivsus \\
Tänapäevasus & Huvitav & Struktuur & Lisamaterjalid \\
Jöukohasus & Loovust toetav & Ülesanded ja tööjuhised & Kujundus \\
Teemaknalisus & Autentsed illustratsioonid & Varasem kasutus- \\
Metoodilisus & & & kogemus \\
\hline
\end{tabular}

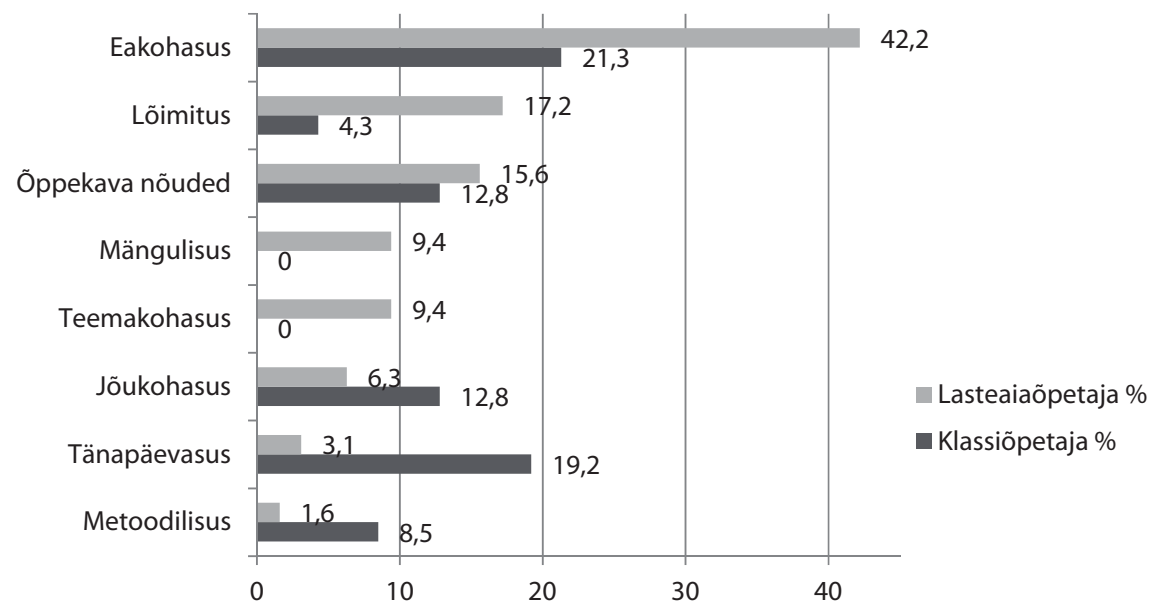

Joonis 2. Peakategooria „Vastavus õppekavale" alamkategooriad kahe õpetajarühma võrdluses (\%).

Selgus, et kolmandik kõigist vastajatest oli märkinud, et õppevara peaks olema lastele eakohane, st ülesanded ja tekstid peaksid olema lastepärased nii kujunduse, kirja suuruse kui ka teiste vormistuslike tunnuste poolest. Ligi pool lasteaiaõpetajatest ja ainult viiendik klassiõpetajatest pidas eakohasust oluliseks õppevara valiku põhimõtteks. Vähem õpetajaid (14,4\% valimist) tõi välja arvestamise õppekava nõuetega ehk selle, et õpik ja töövihik toetaksid õppekavas kirjeldatud ópitulemuste saavutamist. Eri valdkondade ja ainete lõimingut nimetas umbes kümnendik kõikidest õpetajatest (11,7\%), sealhulgas 
oli lasteaiaõpetajaid 17\% ja klassiõpetajaid ainult 4\%. Need õpetajad kirjeldasid, et töövihikus või tööraamatus peaks mitu ainevaldkonda olema integreeritud.

Kõigist vastajatest 9,9\% nimetas õppevara valiku olulise põhimõttena tänapäevasust (nt ajakohane sisu, mis kajastab muutusi keskkonnas). Lasteaiaõpetajatest tõid selle põhimõtte õppevara valikul välja üksikud vastajad, klassiõpetajate hulgas oli tänapäevasust tähtsustavaid õpetajaid rohkem (vt joonis 2). Jõukohasust ehk õppevara vastavust laste arengutasemele ja võimetele mainis 9\% kõikidest õpetajatest, nende hulgas oli lasteaiaõpetajaid poole vähem kui klassiõpetajaid. Samuti nimetati seda, et õppevara raskusaste peaks arvestama laste teadmiste taset ja nn keskmist õpilast. Õppevara mängulisust ja teemakohasust nimetas alla kümnendiku lasteaiaõpetajatest, klassiõpetajad neid kahte valiku põhimõtet välja ei toonud. Kõige vähem nimetasid õpetajad üldse metoodilisust (4,5\% valimist), sagedamini tegid seda klassiõpetajad.

Teise peakategooria „Sisu ja ülesannete mitmekesisus“ moodustasid neli alamkategooriat (vt joonis 3), mille tõi välja 51,6\% lasteaia- ja 38,3\% klassiõpetajatest.

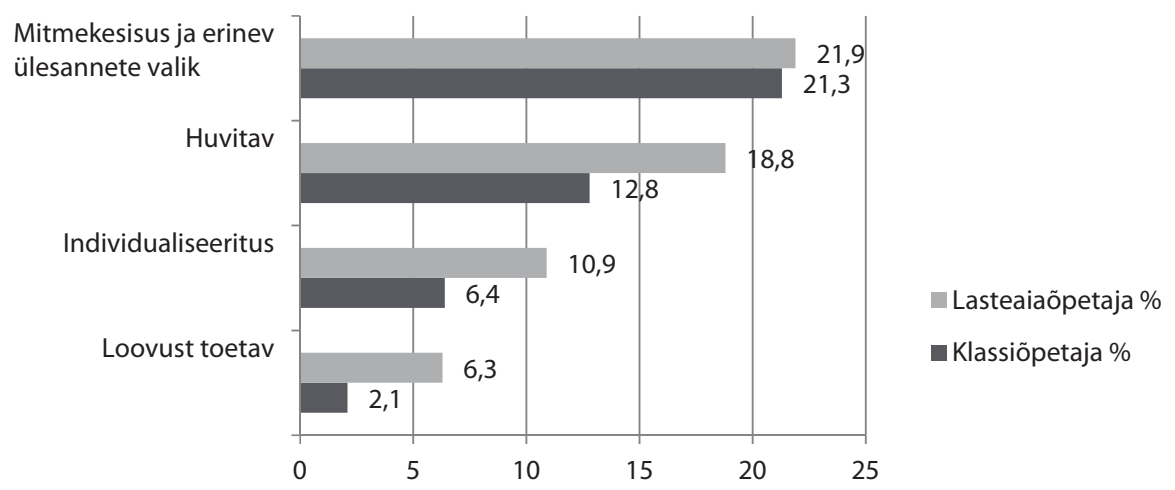

Joonis 3. Peakategooria „Sisu ja ülesannete mitmekesisus“ alamkategooriad kahe õpetajarühma võrdluses (\%).

Peaaegu viiendik lasteaia- ja klassiõpetajatest (kokku 21,6\%) pidas oluliseks nii õppevara sisu kui ka ülesannete valiku mitmekesisust. Õpetajate hinnangul peaksid tekstid, ülesanded ja harjutused olema põnevad ja eriilmelised. Oluliseks peeti ka seda, et õppevara võimaldaks õpetajal arvestada laste huvisid, mõnevõrra rohkem mainisid seda lasteaia- kui klassiõpetajaid. Õppevara valides õpetamise individualiseerimise võimalusega arvestamist märkisid lasteaiaõpetajad mõnevõrra sagedamini kui klassiõpetajad. Samuti oodatakse, et õppevara sisaldaks eri raskusastmega lisaülesandeid andekamatele õpilastele ning sobivaid võimalusi noorematele ja nõrgematele õppijatele. Kõige vähem 
nimetasid lasteaia- ja klassiõpetajad (vaid 4,5\% valimist) lapse loovuse toetamist õppevara toel, mis väljenduks ülesannetes ja võimaluses lapsel ise midagi täiendada, otsustada ja teha.

Kolmandasse peakategooriasse „Sisu ja ülesannete selgus ja arusaadavus“ liigitati samuti neli alamkategooriat, mida nimetas $26,6 \%$ lasteaia- ja $29,8 \%$ klassiõpetajatest.

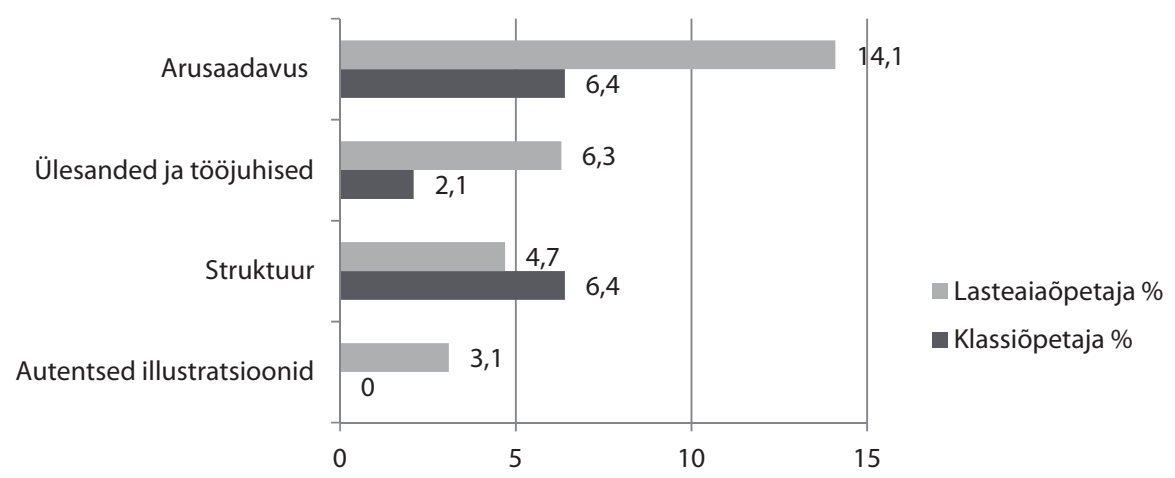

Joonis 4. Peakategooria "Sisu ja ülesannete selgus ja arusaadavus" alamkategooriad kahe õpetajarühma võrdluses (\%).

Joonisel 4 esitatud põhimõtetest nimetasid õpetajad kõige sagedamini õppevara üldist arusaadavust (10,8\% kõigist vastanutest). Võrreldes klassiõpetajatega esines see põhimõte lasteaiaõpetajate vastustes kaks korda sagedamini. Mainiti ka õppevara struktuuri, ülesehituse süsteemsust, loogilisust ja selgust (valimist 5,4\%). Need kriteeriumid muudavad õppevara kasutajasõbralikuks. Vähe nimetati aga ülesannete ja tööjuhiste selgust ja arusaadavust (4,5\% vastanutest), kusjuures sagedamini tõid selle välja lasteaiaõpetajad. Sellesse peakategooriasse liigitatud põhimõtetest tõid lasteaiaõpetajad kõige harvem välja, et õppevara illustratsioonid ja kujundus peaksid olema sisu arvestades asjakohased ja lastele arusaadavad. Klassiõpetajad seda põhimõtet ei nimetanud.

Neljandasse peakategooriasse „Välised tegurid“ koondati viis alamkategooriat, mida nimetas 14,1\% lasteaia- ja 27,7\% klassiõpetajatest (vt joonis 5).

Joonisel 5 toodud põhimõtteid nimetati üldse kõige harvem, neist mõnevõrra sagedamini siiski õppevara atraktiivsust ja lisamaterjalide olemasolu (mõlemaid 5,4\% valimist). Lasteaiaõpetajad nimetasid sagedamini õppevara atraktiivset välimust, st õppevara peaks olema lastele visuaalselt köitev, klassiõpetajatest tõi selle põhimõtte välja üks vastaja. Seevastu kümnendik klassiõpetajatest pidas oluliseks õppevara lisamaterjale, näiteks e-õpikut või kontrolltööde ja tunnikontrollide kogumikku. Nimetati ka õppevara tutvustavaid koolitusi. Lasteaiaõpetajad nimetasid lisamaterjale valiku tegemise 
põhimõttena siiski harvem kui klassiõpetajad. Enam-vähem võrdne oli aga lasteaia- ja kooliõpetajate osakaal, kes pidasid valikul oluliseks õppevara kujundust. Õppevara valiku põhimõtetest nimetati veel varasemat kasutuskogemust („olen varem seda õppevara kasutanud“, „õppevara on eelnevalt tuttav“) või kolleegide soovitust. Lasteaiaõpetajad seda põhimõtet oma vastustes välja ei toonud. Õppevara hind valikupõhimõttena esines samuti vaid mõne õpetaja vastustes (valimist 3,6\%). Klassiõpetajate hulgas oli rohkem neid, kes teevad õppevara valiku soodsama hinna järgi.

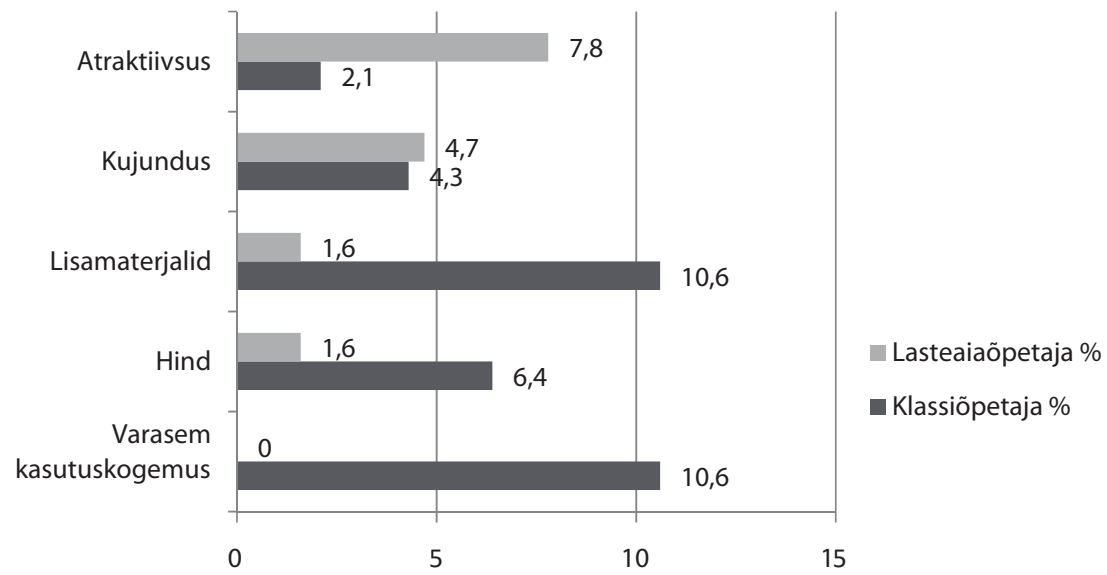

Joonis 5. Peakategooria „Välised tegurid“ alamkategooriad kahe õpetajarühma võrdluses (\%).

Joonisel 5 toodud põhimõtteid nimetati üldse kõige harvem, neist mõnevõrra sagedamini siiski õppevara atraktiivsust ja lisamaterjalide olemasolu (mõlemaid 5,4\% valimist). Lasteaiaõpetajad nimetasid sagedamini õppevara atraktiivset välimust, st õppevara peaks olema lastele visuaalselt köitev, klassiõpetajatest tõi selle põhimõtte välja üks vastaja. Seevastu kümnendik klassiõpetajatest pidas oluliseks õppevara lisamaterjale, näiteks e-õpikut või kontrolltööde ja tunnikontrollide kogumikku. Nimetati ka õppevara tutvustavaid koolitusi. Lasteaiaõpetajad nimetasid lisamaterjale valiku tegemise põhimõttena siiski harvem kui klassiõpetajad. Enam-vähem võrdne oli aga lasteaia- ja kooliõpetajate osakaal, kes pidasid valikul oluliseks õppevara kujundust. Õppevara valiku põhimõtetest nimetati veel varasemat kasutuskogemust („olen varem seda õppevara kasutanud“, „õppevara on eelnevalt tuttav“) või kolleegide soovitust. Lasteaiaõpetajad seda põhimõtet oma vastustes välja ei toonud. Õppevara hind valikupõhimõttena esines samuti vaid mõne õpetaja vastustes (valimist 3,6\%). Klassiõpetajate hulgas oli rohkem neid, kes teevad õppevara valiku soodsama hinna järgi. 


\section{Õpetajate hinnangud õppevara eesmärkide kohta}

Kolmandaks analüüsiti, milliseid eesmärke peaks lasteaia- ja klassiõpetajate hinnangul heal tasemel õppevara täitma. Sisu alusel liigitusid eesmärgid kolme rühma: kognitiivsed $(\max =7)$, afektiivsed $(\max =6)$ ja metakognitiivsed eesmärgid $(\max =5)$.

Tabel 2. Õpetajate hinnangud heal tasemel õppevara eesmärkide kohta

\begin{tabular}{lcccc} 
Eesmärgid & $\begin{array}{l}\text { Lasteaiaõpetajad } \\
\text { Me }\end{array}$ & $\begin{array}{c}\text { Klassiõpetajad } \\
\text { Me }\end{array}$ & $\mathbf{U}$ & $\mathbf{p}$ \\
Kognitiivsed & 6,0 & 7,0 & 1333,5 & 0,28 \\
Afektiivsed & 6,0 & 5,0 & 1355,0 & 0,34 \\
Metakognitiivsed & 2,5 & 4,0 & 1060,0 & $\mathbf{0 , 0 1}$ \\
\hline
\end{tabular}

Märkus. Me - mediaan, U - Mann-Whitney U-statistiku väärtus, p - olulisusnivoo

Võrreldes lasteaia- ja klassiõpetajate valitud eesmärkide koondmediaane, ilmnes statistiliselt oluline erinevus metakognitiivsete eesmärkide rühmas. Nimelt pidasid klassiõpetajad hea õppevara puhul lasteaiaõpetajatest olulisemaks, et õppevara aitaks saavutada eesmärke, mis on suunatud laste metakognitiivsete oskuste arengule ( $\mathrm{p}<0,05$, vt tabel 2). Kognitiivsete ja afektiivsete eesmärkide puhul kahe õpetajarühma vahel statistiliselt olulisi erinevusi ei ilmnenud.

\section{Arutelu}

Õigus otsustada õppevara valiku üle on õpetaja jaoks tähtis, see peab toetama laste kognitiivsete, sotsiaalsete, afektiivsete ja metakognitiivsete oskuste arengut. Samuti peaksid eri kooliastmete õpetajad olema tuttavad õppevaraga, mida kasutatakse eelmises või järgmises kooliastmes, sest nii saab õpetaja toetada tõhusamalt laste üleminekut ühest kooliastmest teise (Onyango, 2014). Siinsest uuringust selgus, et lasteaiaõpetajatel on klassiõpetajatest suurem otsustusõigus valida ise õppevara eesti keele ja matemaatika õpetamisel. Õppevara valiku põhimõtetest tõid mõlema rühma õpetajad kõige sagedamini välja õppevara eakohasuse ning selle, et õppevara oleks laste jaoks mitmekesine ja arusaadav. Küsimuse puhul, milliseid eesmärke peaks täitma heal tasemel õppevara, ilmnes lasteaia- ja klassiõpetajate vahel märkimisväärne erinevus: klassiõpetajad pidasid olulisemaks, et õppevara võimaldaks saavutada metakognitiivseid eesmärke. Teades, millistest põhimõtetest lähtuvad lasteaia- ja klassiõpetajad õppevara valikul ning milliste eesmärkide täitmist nad õppevara abil saavutada püüavad, saab tõhusamalt toetada laste igakülgset arengut üleminekul lasteaiast kooli. 


\section{Otsustusõigus ja valikupõhimõtted õppevara puhul}

Uuringus selgitati välja, kuivõrd saavad lasteaia- ja klassiõpetajad ise otsustada, millist õppevara kasutada eesti keele (lasteaias keele ja kõne) ning matemaatika õpetamisel. Õpetajatelt eeldatakse lapse arengu tundmist ja oskust valida õppevara, mis vastab laste arengutasemele ja eripärale (Kutsestandard, 2020; õpetaja tase 6 ja tase 7). Seejuures peab õpetaja arvestama õpieesmärke, märkama ôppevara puudusi ning tegema ettepanekuid õppevara kohandamiseks vastavalt laste arengutasemele. Siinsest uuringust selgus, et kõigil lasteaiaõpetajatel on suuremal või natuke vähemal määral võimalus ise otsustada, millist õppevara valida keele ja kõne valdkonna või eesti keele või matemaatika õpetamiseks. Enamik klassiõpetajaid saab endi sõnul õppevara valikut küll mingil määral suunata, kuid üle kümnendikul klassiõpetajatest selline otsustusõigus puudub. Ka varasematest uurimustest on selgunud, et kooliõpetajatel sellist valikuvõimalust alati ei ole (Lalau, 2014; Reichenberg \& Andreassen, 2017). Küsimusele, miks on lasteaiaõpetajatel võrreldes klassiõpetajatega õppevara valikul suurem otsustusõigus, leiab mitmeid selgitusi.

Lasteaias toimub laste arendamine ja õppeülesannete täitmine suuresti mängu kaudu (Gustafsson \& Mellgren, 2010; Niikko \& Ugaste, 2012 ) ja õppevara kasutus on vabam. Samas selgub varasematest uurimustest, et lasteaia roll laste akadeemilises ettevalmistamises on järjest suurenenud ja lasteaed muutunud koolilikumaks. See on suurendanud ka kooliliku õppevara kasutust lasteaias (Bassok et al., 2016; Neudorf et al., 2017), sealhulgas tööraamatute ja -lehtede ning mitut liiki raamatute kasutust (Nugin, 2018). Samas, kui õpetajal on õigus ja vabadus valida õppevara, siis peavad tal olema teadmised, kuidas valida nii, et õppevarast oleks laste õppimisele võimalikult suur kasu. Selleks tuleks koolijuhtkonna liikmete hulgas kujundada hoiakut, et õpetaja on ekspert, keda võib õppevara valikul usaldada (Taimalu et al., 2020).

Teiseks uuriti, milliseid põhimõtteid peavad lasteaia- ja klassiõpetajad oluliseks eesti keele ja matemaatika õppevara valikul. Põhimõte, mida lasteaia- ja klassiõpetajad kõige sagedamini nimetasid, oli õppevara eakohasus. Selline tulemus on positiivne, kuna õppevara valides tuleb arvestada laste arengut. Samas ilmnes, et õppevara eakohasust pidas oluliseks ainult viiendik klassiõpetajatest. Seda vaatamata asjaolule, et eakohasust õppevara valikul on rõhutatud nii põhikooli riiklikus õppekavas (2011/2014) kui ka varasemates uuringutes (nt Bartan, 2011; Birhan, 2018; Braga, 2014). Õppevara eakohasusega on tihedasti seotud selle jõukohasus ehk vastavus laste arengutasemele ja võimetele (Gürkaynak, 2015; Czeglédy \& Kovács, 2008). Klassiõpetajad nimetasid jõukohasust olulise valikupõhimõttena rohkem kui lasteaiaõpetajad. Üheks põhjenduseks võib olla see, et lapse arengutasemele vastavat diferentseeritud õpetamist rõhutatakse koolis rohkem kui alushariduses (vt 
koolieelse lasteasutuse riiklik õppekava, 2008; põhikooli riiklik õppekava, 2011/2014).

Üsna võrdsel määral nimetasid lasteaia- ja klassiõpetajad óppevara vastavust õppekavale. See on ootuspärane, kuna õppevara peab toetama õppekava eesmärkide täitmist ning neid eesmärke, vastupidi, tuleb arvestada õppevara koostamisel (Braga, 2014; Howard \& Major, 2004). Samas on mõnevõrra üllatav, et selle põhimõtte tõi välja veidi enam kui kümnendik õpetajatest. Ilmselt pidasid vastajad õppevara vastavust õppekavale nii enesestmõistetavaks, et ei nimetanud seda eraldi põhimõttena. Suuremad erinevused lasteaia- ja klassiõpetajate rühma vahel ilmnesid aga õppevara lõimituse ja mängulisuse puhul. Nii pidasid lasteaiaõpetajad lõimingut õppevara valikul olulisemaks kui klassiõpetajad ning ükski klassiõpetaja ei nimetanud mängulisust õppevara valiku olulise põhimõttena.

Lasteaia- ja klassiõpetajad tõid enam-vähem võrdselt välja, et õppevara peab olema mitmekesine nii sisult kui ka ülesannete ja harjutuste poolest. Mitmekesisus on tähtis, sest see pakub arenguvõimalust nii andekamatele (Czeglédy \& Kovács, 2008) kui ka nõrgematele õpilastele (Gürkaynak, 2015). Õpetuse individualiseerimist pidasid oluliseks ka siinses uuringus osalenud õpetajad. Peale individuaalsete ülesannete on aga oluline, et õppevara sisaldaks ülesandeid, mis võimaldavad õpilaste omavahelist koostööd (Kirkgöz, 2009). Ometi selgus siinses uuringus, et koostöise õppimise toetamist õppevara valiku olulisemate põhimõtete seas ei olnud. Ilmselt kasutavad õpetajad koostöist õppimist õppeprotsessis piisavalt ning koostöö toetamist õppevara abil ei peeta nii oluliseks, et nimetada seda õppevara kõige olulisemate valikupõhimõtete hulgas.

Lisaks selgus, et uuringus osalenud õpetajate seas oli vähe neid, kes pidasid õppevara puhul tähtsaks toetada laste loovust. Uuenenud õpikäsituse järgi on loovuse arendamine tähtis ning ülesandeid hoolikalt kavandades saab sellele kaasa aidata (Geisinger, 2016; Lebeda et al., 2018). Samas tuleb meeles pidada, et siinses uuringus paluti õpetajatel välja tuua kolm põhimõtet, mida nad peavad eesti keele ja matemaatika õppevara valides oluliseks. Võib olla on loovuse arendamine õpetajate jaoks olulisem andeainetes (nt kunstiõpetuses, käsitöös ja muusikas) ning vähem oluline põhimõte eesti keele ja matemaatika õppevara valikul. Niisiis ei saa teha järeldust, et loovuse arendamine ei ole enamiku vastanute jaoks oluline, vaid see võib olla oluline põhimõte teistes ainevaldkondades.

Õpetamist toetab ka õppevara sisu selgus ja arusaadavus (Ho \& Hsu, 2011) ning tööjuhiste mõistetavus (Howard \& Major, 2004). Siinses uuringus osalenud lasteaiaõpetajad nimetasid neid põhimõtteid klassiõpetajatest sagedamini, mis on mõnevõrra üllatav. Just noorema kooliastme õpilaste puhul peetakse oluliseks tekstide lihtsat loetavust, sisu selgust ja tööjuhiste arusaadavust 
(Reicheberg, 2014), toetamaks baasoskuste ning teadmiste edenemist ning õppimist emakeeles (Sousa \& Dionisio, 2011). Nende põhimõtete vähene nimetamine klassiõpetajate poolt võib olla tingitud asjaolust, et Eesti koolis eeldatakse lastelt sageli kõrgema taseme oskusi, kui on välja toodud riiklikus õppekavas ja mida koolimineja oskama peaks (Kukk, 2010).

Õppevara sisu iseloomustavate põhimõtete kõrval võivad õppevara valikut mõjutada ka välised tegurid, näiteks välimus ja hind (Reints \& Wiklens, 2019). Välistest teguritest nimetasid lasteaiaõpetajad kõige enam atraktiivsust ning klassiõpetajad õppevara lisamaterjale. Varasemates uuringutes on leitud, et õpetajad peavad oluliseks õppevara terviklikkust, st selle juurde kuuluvaid abimaterjale, näiteks tööraamatut, õpetajaraamatut, CD-d (Czeglédy \& Kovács, 2008; Sousa \& Dionisio, 2011). Ka siinses uuringus osalenud klassiõpetajad pidasid tähtsaks, et õppevara juurde kuuluksid peale õpiku või töövihiku näiteks harjutusvihik, kontrolltööde kogumik ja õpetajaraamat. Kuna klassiõpetaja õpetab esimeses kooliastmes eri õppeaineid, siis on sellised õppevarakomplektid abiks, säästmaks aega lisalahenduste otsimisel. Aja säästmisega võib olla seotud ka see, et siin uuringus osalenud klassiõpetajad tõid esile, et peavad oluliseks õppevara, mille kasutuskogemus on neil varasemast olemas. Lasteaiaõpetajad seda põhimõtet ei nimetanud. Üheks põhjuseks võib olla lasteaiaõpetajate suurem valmisolek mitmekesistada õpet uue õppevaraga. Teiseks põhjuseks aga see, et klassiõpetajad tunnevad õppevara valikul suuremat vastutust kui lasteaiaõpetajad. Nimelt, koolis hinnatakse laste õpitulemusi ning õppevara peab toetama lapsi koduste õpiülesannete täitmisel. Seega võib klassiõpetajate fookus õppevara valikul olla teistsugune kui lasteaiaõpetajatel, kelle otsustusõigus õppevara valikul on suurem.

\section{Õppevara eesmärgid õpetajate hinnangul}

Järgmisena analüüsiti, milliseid eesmärke peaks lasteaia- ja klassiõpetajate hinnangul täitma heal tasemel õppevara. Klassiõpetajad hindasid lasteaiaópetajatest olulisemaks eesmärke, mis toetavad laste metakognitiivsete oskuste kujunemist. Põhjus võib peituda selles, et lasteaia- ja klassiõpetajad tegelevad eri vanuses lastega ning lasteaiaõpetajad võivad pidada lasteaialapsi liiga nooreks, et pakkuda neile kõrgema tasandi oskusi arendavaid ülesandeid ja harjutusi, mis võimaldavad lastel oma tegevust hinnata (Howard \& Major, 2004). Õppija kujunemist ennastjuhtivaks peetakse oluliseks Eesti haridussüsteemi igal astmel (HTM, s.a.). Seepärast peaks õppevara toetama ka selliste metakognitiivsete oskuste kujunemist, mis on seotud oma õppimise jälgimise, analüüsimise ja juhtimisega (Littlejohn, 2011) ning aitab kaasa õppimisele ja hilisemale õpiedule koolis (Bryce et al., 2015). Nii tuleks lasteaiaõpetajatele 
selgitada metakognitiivsete õpioskuste tähtsust ning seda, miks tuleks nende kujundamisega alustada lastele mõistetaval tasemel juba lasteaias (Howard \& Major, 2004; Mikk, 2000).

Kognitiivseid ja afektiivseid eesmärke pidasid õppevara puhul tähtsaks nii lasteaia- kui ka klassiõpetajad. Eesti alusharidus on muutunud aasta-aastalt koolilikumaks (Neudorf et al., 2017) ja laste koolivalmidust peavad väga oluliseks lapsevanemad. Nii on laste kognitiivsete oskuste arendamine tähtis eesmärk lasteaias ja koolis. Afektiivseid oskusi, mis on seotud laste motivatsiooni ja huviga, emotsionaalse kohanemisega õpiprotsessis (Fahyuan et al., 2018) ja mis aitavad toime tulla ebaeduga õppimisel (Hattie et al., 1996), pidasid uuringus osalenud lasteaia- ja klassiõpetajad oluliseks võrdsel määral. Õpimotivatsiooni toetamist peetakse üldse kõige tähtsamaks afektiivseks eesmärgiks, mida õppevara puhul jälgida (Reints \& Wilkens, 2019; Tomlinson, 2011). Seda tuleb silmas pidada nii õppevara sisu (Braga, 2014) kui ka ülesannete ja harjutuste valikul, sest huvil ja motivatsioonil on laste tulemustele eri õppeainetes otsene mõju (vt nt Käsper et al., 2018).

\section{Piirangud ja soovitused}

Lasteaia- ja klassiõpetajate õppevara valiku võimalusi, otsuseid, põhimõtteid ja eesmärke käsitleval uuringul on mõned metoodilised piirangud. Nimelt, kõik valimisse kaasatud õpetajad töötasid ülikoolide innovatsioonikoolides ja -lasteaedades või praktikakoolides. Seetõttu võisid vastajatel olla nii paremad võimalused, teadmised kui ka oskused, kuidas valida õppevara. See seab piirangud tulemuste üldistamisele kõikidele Eesti lasteaia- ja klassiõpetajatele. Edaspidi vääriks uurimist, millised on väljaspool praktikakoolide võrgustikku töötavate õpetajate võimalused ning milliseid põhimõtteid ja eesmärke nad peavad õppevara valikul oluliseks. Teiseks piiranguks on uuringus kasutatud enesekohane küsimustik, mis oli sobiv vahend õpetajate arvamuste ja hinnangute väljaselgitamiseks, kuid ei andnud teadmist selle kohta, kuidas õpetajad tegelikult õppevara valivad. Kolmandaks, kuna õpetajatel oli võimalus ankeedis välja tuua kolm olulisemat õppevara valiku põhimõtet, siis ei saa teha järeldust, et õpetajad teisi põhimõtteid õppevara valikul oluliseks ei pea. Kombineerides vaatlust intervjuuga, tuleks edaspidi välja selgitada õpetajate oskused valida ja hinnata olemasolevat óppevara ning koostada ise uut õppevara. Neljandaks, õpetajatelt küsiti arvamust ainult kahe aine/valdkonna (eesti keele ja matemaatika) kohta. See ei võimaldanud teada saada, millised on õppevara valiku üldised põhimõtted, millest õpetajad lähtuvad õppevara valikul olenemata õppeainest. 
Uuringu tulemuste põhjal saab anda praktilisi soovitusi.

1) Teades, milliseid põhimõtteid ja eesmärke peavad lasteaia- ja klassiõpetajad oluliseks eesti keele ja matemaatika õppevara puhul, tuleks pöörata tähelepanu õppevara valiku ja hindamisega seotud teemadele õpetajate esma- ja täienduskoolituste kavades, parendades olemasolevaid ning pakkudes välja uusi.

2) Selle põhjal, et lasteaiaõpetajad ei pidanud metakognitiivseid eesmärke õppevara puhul nii oluliseks kui klassiõpetajad, ei saa teha järeldust, et lasteaias metakognitiivsete oskuste kujunemisele tähelepanu ei osutata. Siiski tuleks lasteaiaõpetajate ettevalmistuses tegelda rohkem sellega, kuidas kujundada laste metakognitiivseid oskusi, sealhulgas alushariduses kasutatava õppevara abil.

3) Klassiõpetajate otsustusvabadus ja võimalused valida ise sobiv õppevara olid piiratumad kui lasteaiaõpetajatel. Seetõttu oleks tarvis tõsta kooli juhtkonna ja eelkõige õppejuhtide teadlikkust, kuidas kaasata õpetajaid kui õppeaine eksperte valima kooli õppevara.

\section{Tänusõnad}

Uurimust on toetatud Euroopa sotsiaalfondi projektist 2014-2020.1.02.18-0645, „Tartu Ülikooli õpetajahariduse kompetentsikeskuse Pedagogicum teadus- ja arendusvõimekuse tõstmine“. 


\section{Lisa 1. Õppevara eesmärgid, mille hulgast õpetajad tegid valiku}

Kognitiivsed eesmärgid $(N=7)$

1 arendada probleemilahendamise oskust

2 rakendada teadmisi

3 õpetada esitama oma arvamust

4 arendada analüüsioskust

5 kujundada teemast arusaamist

6 harjutada meeldejätmist

7 süstematiseerida teadmisi

Afektiivsed eesmärgid $(\mathrm{N}=6)$

8 toetada õpimotivatsiooni

9 suunata õpilasi keskenduma õppimisele

10 arvestada õppija huve

11 saada eduelamust

12 toetada iseseisvust

13 toetada sobilike käitumisharjumuste teket

Metakognitiivsed eesmärgid $(N=5)$

14 teadvustada õppimise eesmärke

15 suunata õpilasi analüüsima enda õppimist

16 jälgida oma tegevust õppimisel

17 aidata õpilasel oma aega planeerida

18 suunata õpilasi hindama oma õppimise tõhusust 


\section{Kasutatud kirjandus}

Ahtola, A., Silinskas, G., Poikonen, P. L., Kontoniemi, M., Niemi, P., \& Nurmi, J. E. (2011). Transition to formal schooling: Do transition practices matter for academic performance?. Early Childhood Research Quarterly, 26(3), 295-302. https://doi.org/10.1016/j.ecresq.2010.12.002

Aunio, P., \& Niemivirta, M. (2010). Predicting children's mathematical performance in grade one by early numeracy. Learning and Individual Differences, 20(5), 427435. https://doi.org/10.1016/j.lindif.2010.06.003

Babic, D. P., \& Baucal, A. (2011). The big improvement in PISA 2009 reading achievements in Serbia: Improvement of the quality of education or something else? CEPS Journal: Center for Educational Policy Studies Journal, 1(3), 53-74.

Bartan, M. (2018). Determination of Preschool Teachers' Preference Reasons for Children's Books Used by Them in Their Classes. World Journal of Education, 8(6), 187-195. https://doi.org/10.5430/wje.v8n6p187

Bassok, D., Latham, S., \& Rorem, A. (2016). Is kindergarten the new first grade?. AERA Open, 2(1). https://doi.org/10.1177/2332858415616358

Bazeley, P. (2013). Qualitative data analysis: Practical strategies. Sage.

Birhan, W. (2018). Analysis of preschool curriculum in East Gojjam Zone: Implication to quality early childhood education. Educational Research and Reviews, 13(14), 557-563. https://doi.org/10.5897/ERR2018.3577

Braga Garcia, T. M. F. (2014). Criteria Used by Teachers in Brazilian Public Elementary Schools in the Process of Textbook Selection. Orbis Scholae, 8(2), 9-22. https://doi.org/10.14712/23363177.2015.63

Bryce, D., Whitebread, D., \& Szücs, D. (2015). The relationships among executive functions, metacognitive skills and educational achievement in 5 and 7 year-old children. Metacognition and Learning, 10(2), 181-198. https://doi.org/10.1007/s11409-014-9120-4

Chou, J. (2003). Criteria for selecting quality environmental education teaching materials in Taiwan. Applied Environmental Education and Communication: An International Journal, 2(3), 161-168. https://doi.org/10.1080/15330150390218289

Czeglédy, I., \& Kovács, A. (2008). How to Choose a Textbook on Mathematics?. Acta Didactica Napocensia, 1(2), 16-30.

Erss, M., Kalmus, V., \& Autio, T. H. (2016). 'Walking a fine line': Teachers' perception of curricular autonomy in Estonia, Finland and Germany. Journal of Curriculum Studies, 48(5), 589-609. https://doi.org/10.1080/00220272.2016.1167960

Fahyuan, D. T., Atmazaki, A., \& Ermanto, E. (2018, December). The Development of CTL Based Reading Description Text Learning Material. In International Conference on Language, Literature, and Education (ICLLE 2018). Atlantis Press.

Geisinger, K. F. (2016). 21st century skills: What are they and how do we assess them?. Applied Measurement in Education, 29(4), 245-249. https://doi.org/10.1080/08957347.2016.1209207

Griffith, P. L., \& Ruan, J. (2005). What is metacognition and what should be its role in literacy instruction? In Susan E. Israel, Cathy C. Block, Kathry. L. Bauserman, \& Kathryn Kinnucan-Welsch (Eds.), Metacognition in Literacy Learning. Theory, Assessment, Instruction, and Professional Development (pp. 25-40). London: Lawrence Erlbaum Associates. 
Gustafsson, K., \& Mellgren, E. (2002). Using text in pre-school: A learning environment. Early Child Development and Care, 172(6), 603-624. https://doi.org/10.1080/03004430215103

Gürkaynak, E. (2015). A textbook adaptation using data gathered by a multiple intelligence inventory. Procedia-Social and Behavioral Sciences, 199, 285-292. https://doi.org/10.1016/j.sbspro.2015.07.518

Hansen, T. I., \& Gissel, S. T. (2017). Quality of learning materials. IARTEM e-Journal, 9(1), 122-141. https://doi.org/10.21344/iartem.v9i1.601

Hattie, J., Biggs, J., \& Purdie, N. (1996). Effects of learning skills interventions on student learning: A meta-analysis. Review of Educational Research, 66(2), 99-136. https://doi.org/10.3102/00346543066002099

Ho, H. F., \& Hsu, Y. T. (2011). Improving the Textbook Adoption Process in Taiwan. International Education Studies, 4(4), 92-98. https://doi.org/10.5539/ies.v4n4p92

Howard, J., \& Major, J. (2004). Guidelines for designing effective English language teaching materials. The TESOLANZ Journal, 12(10), 50-58.

HTM (s.a.). Õpikäsitus. Külastatud aadressil https://www.hm.ee/et/opikasitus

Kurkgöz, Y. (2009). Evaluating the English textbooks for young learners of English at Turkish primary education. Procedia-Social and Behavioral Sciences, 1(1), 79-83. https://doi.org/10.1016/j.sbspro.2009.01.016

Koolieelse lasteasutuse riiklik õppekava (2008). Riigi Teataja I, 2008, 23, 152. Külastatud aadressil https://www.riigiteataja.ee/akt/13351772

Kukk, A. (2010). Õppekava eesmärkide saavutamine üleminekul lasteasutusest kooli ning I kooliastmes õpetajate hinnanguil. Doktoritöö. Tallinna Ülikool.

Kulderknup, E. (2009). Saateks. E. Kulderknup (toim), Oppe- ja kasvatustegevuse valdkonnad (lk 5). Tallinn: Kirjastus Studium.

Kutsestandard (2020). Õpetaja, tase 6 ja tase 7. Külastatud aadressil https://www.kutseregister.ee

Kärbla, T., Uibu, K., \& Männamaa, M. (2017). Eesti keele riiklike tasemetööde tekstimõistmisülesannete analüüs. Eesti Rakenduslingvistika Ühingu aastaraamat, 13, 73-87. https://doi.org/10.5128/ERYa13.05

Käsper, M., Uibu, K., \& Mikk, J. (2018). Language Teaching Strategies' Impact on Third-Grade Students' Reading Outcomes and Reading Interest. International Electronic Journal of Elementary Education, 10 (5), 601-610. https://doi.org/10.26822/iejee.2018541309

Lalau, E. (2014). Teachers', Pupils', and Parents' Opinions on Primary Textbooks: Their Selection, Quality and Use. Acta Didactica Napocensia, 7(3), 59-71.

Lebeda, I. L., Mijoc, J., \& Tomašević, N. (2018). Critical examination of the IEET measurement instrument for the assessment of textbook quality. Ekonomski vjesnik/Econviews-Review of Contemporary Business, Entrepreneurship and Economic Issues, 31(2), 275-286.

Leppänen, U. (2006). Development of literacy in kindergarten and primary school (No. 289). Jyväskylän yliopisto.

Littlejohn, A. (2011). The analysis of language teaching materials: Inside the Trojan Horse. In B. Tomlinson, Materials Development in Language Teaching. (2nd edn). Cambridge University Press. 
Lopera Medina, S. (2015). The design process of a reading comprehension manual. Colombian Applied Linguistics Journal, 17(1), 130-141.

https://doi.org/10.14483/udistrital.jour.calj.2015.1.a09

Mayer, R. E. (2002). Rote versus meaningful learning. Theory into Practice, 41(4), 226-232. https://doi.org/10.1207/s15430421tip4104_4

Miekley, J. (2005). ESL textbook evaluation checklist. The Reading Matrix, 5(2).

Mikk, J. (2000). Textbook: Research and Writing. Baltische Studien zur Erziehungs und Sozialwissenschaft, Band 3 (Baltic Studies for Education and Social Sciences, Volume 3). Peter Lang Publishing.

Nemati, A. (2009). Evaluation of an ESL English course book: A step towards systematic vocabulary evaluation. Journal of Social Sciences, 20(2), 91-99.

https://doi.org/10.1080/09718923.2009.11892726

Neudorf, E., Ugaste, A., Tuul, M., \& Mikser, R. (2017). Lasteaiaõpetajate uskumused seoses laste üldoskuste arendamisega riikliku õppekava alusel: lisaseletus lasteaia koolistumise põhjustele. Eesti Haridusteaduste Ajakiri, 5(2), 54-79.

https://doi.org/10.12697/eha.2017.5.2.03

Niikko, A., \& Ugaste, A. (2012). Conceptions of Finnish and Estonian pre-school teachers' goals in their pedagogical work. Scandinavian Journal of Educational Research, 56(5), 481-495. https://doi.org/10.1080/00313831.2011.599424

Nugin, K. (2018). Keel ja kõne. K. Nugin, T. Õun (koost), Õppe- ja kasvatustegevus lasteaias (lk 211-226). Atlex Kirjastus.

Onyango, W. P. (2014). Effects of Teaching and Learning Resources on preschool learners Transition to class one; A case study of rachuonyo South Subcounty. Journal of Education and Practice, 5(34).

Palu, A. (2008). Matemaatika. E. Kikas (toim), Õppimine ja õpetamine koolieelses eas (lk 322-333). Tartu: Tartu Ülikooli Kirjastus.

Peterson, T., Tuul, M., \& Veisson, M. (2013). Koolieelse lasteasutuse õpetaja professionaalsus. E. Krull, Ä. Leijen, M. Lepik, J. Mikk, L. Talts, \& T. Õun (toim), Õpetajate professionaalne areng ja selle toetamine (lk 83-102). Eesti Ülikoolide Kirjastus.

Põhikooli riiklik õppekava (2011/2014). Riigi Teataja I, 2018, 8. Külastatud aadressil https://www.riigiteataja.ee/akt/114022018008

Reichenberg, M. (2014). Predicting teachers' choice of teaching and learning materials: A survey study with Swedish teachers. IARTEM e-Journal, 6(2), 71-93.

Reichenberg, M., \& Andreassen, R. (2017). Similar but not the same: Comparing Norwegian and Swedish teachers' influence on textbook selection and involvement in text discussions. IARTEM e-Journal, 9(1), 4-27. https://doi.org/10.21344/iartem.v9i1.596

Reints, A. J., \& Wilkens, H. J. (2019). How teachers select textbooks and educational media. IARTEM 1991-2016: 25 years developing textbook and educational media research, 99.

Resnick, I., Verdine, B. N., Golinkoff, R., \& Hirsh-Pasek, K. (2016). Geometric toys in the attic? A corpus analysis of early exposure to geometric shapes. Early Childhood Research Quarterly, 36, 358-365. https://doi.org/10.1016/j.ecresq.2016.01.007

Riffe, D., Lacy, S., \& Fico, F. (2005). Analyzing media messages: Using quantitative content analysis in research. Lawrence Erlbaum Associated, Publishers, London.

Samuels, S. J., Ediger, K. M., Willcutt, J. R., \& Palumbo, T. J. (2005). Role of automaticity in metacognition and literacy instruction. In S. E. Israel, C. C. Block, 
K. L. Bauserman, \& K Kinnucan-Welsch (Eds.), Metacognition in literacy learning: Theory, assessment, instruction, and professional development (pp. 41-59). Mahwah, NJ: Erlbaum

Sánchez, D. O., de la Cal, E. S., \& Quintana, J. I. (2019). Literacies and the development of social, critical, and creative thought in textbook activities for Primary Education in Social Sciences and the Spanish Language. Frontiers in Psychology, 10, 25-72. https://doi.org/10.3389/fpsyg.2019.02572

Sousa, J., \& Dionísio, M. D. L. (2011). Evaluation and selection of textbooks in Portugal: perceptions from mother tongue teachers. In Natalija Maziekeine, Mike Horsley \& Susanne V. Knudsen (Eds.). The Eleventh International Conference on Research on Textbook and Educational Media: Representation of otherness. Kaunas: IARTEM.

Taimalu, M., Uibu, K., Luik, P., Leijen, Ä., \& Pedaste, M. (2020). Õpetajad ja koolijuhid väärtustatud professionaalidena. OECD rahvusvahelise õpetamise ja õppimise uuringu TALIS 2018 uuringu tulemused. 2., 1-114.

Tomlinson, B. (2011). Introduction: Principles and procedures of materials development. In B. Tomlinson, Materials Development in Language Teaching. (2nd edn). Cambridge University Press.

Tomlinson, B., \& Masuhara, H. (2017). The complete guide to the theory and practice of materials development for language learning. John Wiley \& Sons.

Tuul, M., Mikser, R., Neudorf, E., \& Ugaste, A. (2015). Estonian preschool teachers' aspirations for curricular autonomy - the gap between an ideal and professional practice. Early Child Development and Care, 185(11-12), 1845-1861.

https://doi.org/10.1080/03004430.2015.1028387

Uibu, K., \& Kikas, E. (2014). Authoritative and authoritarian-inconsistent teachers' preferences for teaching methods and instructional goals. Education 3-13, 42(1), 5-22. https://doi.org/10.1080/03004279.2011.618808

Uibu, K., Mikk, J., Taimalu, M., \& Kärbla, T. (2020). Pre- and primary school teachers' assessment on the importance of quality criteria of learning materials. Avaldamata käsikiri.

Uibu, K., Salo, A., Ugaste, A., \& Rasku-Puttonen, H. (2017). Beliefs about teaching held by student teachers and school-based teacher educators. Teaching and Teacher Education, 63, 396-404. https://doi.org/10.1016/j.tate.2017.01.016

Ugaste, A., Neudorf, E., Sarap, A., Saar, K., \& Elissaar, E. (2019). 100 óppemängu lastele. Eesti Alushariduse Ühendus.

Viirpalu, P., Krull, E., \& Mikser, R. (2014). Investigating Estonian teachers' expectations for the general education curriculum. Journal of Teacher Education for Sustainability, 16(2), 54-70. https://doi.org/10.2478/jtes-2014-0011

Võgotski, L. (2016). Laste loovus ja kujutlusvõime. Mäng ja selle osa lapse psüühilises arengus. Tallinn: TLÜ Kirjastus

Wilkens, H. J. (2011). Textbook approval systems and the Program for International Assessment (PISA) results: A preliminary analysis. IARTEM e-Journal, 4(2), 63-74.

Õppekirjandusele esitatavad nõuded, õppekirjanduse retsenseerimisele ja retsensentidele esitatavad miinimumnõuded ning riigi poolt tagatava minimaalse õppekirjanduse liigid klassiti ja õppeaineti (2016). Riigi Teataja I, 2016. Külastatud aadressil https://www.riigiteataja.ee/akt/129032016001 


\title{
Principles and goals that determine the choice of Estonian language and mathematics learning materials as reported by pre-school and primary school teachers
}

\author{
Merle Taimalua ${ }^{\text {a }}$ Krista Uibu ${ }^{\text {a }}$, Heily Leola ${ }^{a^{1}}$ \\ a Institute of Education, University of Tartu
}

\section{Summary}

\section{Introduction}

In the case of learning materials, it is important to support the achievement of instructional goals and the development of pupils' cognitive and social competencies (Tomlinson \& Masuhara, 2017). Teachers should be knowledgeable of high-quality learning materials (Lebeda et al., 2018) and have the skills to choose them. The quality criteria and principles of selection of learning materials have been discussed mainly in the school context, and much less in the pre-school situation. Pre-school education has become more school-like during the last decades (Bassok et al., 2016; Neudorf et al., 2017) and, therefore, more attention should be paid to learning materials at this stage of education. National standards and earlier studies have shown five types of principles that guide teachers in selecting learning materials.

First, the teacher must have the skills and opportunities to select learning materials that are age-appropriate for pupils and correspond to their characteristics (Basic School National Curriculum 2011/2014). However, they do not always have the opportunity to make such choices (Reichenberg \& Andreassen, 2017), are unable to cope with the selection or may not have the expertise to compile these materials. Second, good learning materials should be in line with instructional and methodological choices. It has become clear that the preschool curriculum does not always take into account the age of the children. For example, teachers may use memorising instead of game-based learning and child-centred activities. Third, good learning materials should be affordable at age-appropriate and weaker levels (Gürkaynak, 2015) as well as challenging for those more talented (Czeglédy \& Kovács, 2008). The age-appropriateness of materials is characterised by the clarity of content (Ho \& Hsu, 2011), logic of structure (Lebeda et al., 2018) and comprehensibility of instructions (Howard

Institute of Education, University of Tartu, Salme 1a, Tartu, 50103 Estonia; heily.leola@ut.ee 
$\&$ Major, 2004). Fourth, materials should include, in addition to text- or workbook, test materials and a teacher's book (Czeglédy \& Kovács, 2008). Fifth, design of materials (e.g. authentic pictures) is important (Birhan, 2015).

Good learning materials help teachers in achieving cognitive, affective and metacognitive goals. The development of cognitive skills is supported by the variety of exercises in the study material (Lopera, 2015; Mikk, 2000). Affective skills are important for concentrating on the learning process, coping with failures in learning (Hattie et al., 1996) and motivating pupils (Fahyuan et al., 2018). To support metacognitive skills, the tasks of learning materials should allow pupils to evaluate their own performance (Howard \& Major, 2004).

The international study TALIS has revealed that, compared to other OECD countries, Estonian tertiary teachers have autonomy over the use of learning materials (Taimalu et al., 2020). Pre-school teachers also want freedom of choice and opportunities to choose their learning materials (Tuul et al., 2015). However, the autonomy and responsibilities of teachers of first school stages in using learning materials have not been studied in Estonia. The aim of this study was to find the rationale of how Estonian pre-school and primary school teachers decide on the choice of Estonian language and mathematics learning materials, what principles they follow and what goals they consider important for learning materials. The differences between pre-school and primary school teachers were analysed based on three research questions.

1. To what extent can pre-school and primary school teachers decide which learning materials to use in the instruction of the Estonian language and mathematics?

2. What principles do pre-school and primary school teachers consider important in the selection of Estonian language and mathematics learning materials?

3. Which goals should high quality learning materials fulfil in the opinion of pre-school and primary school teachers?

\section{Method}

The sample consisted of 111 teachers, including 64 pre-school and 47 primary school teachers. Pre-school teachers' average age was 46.7 and teaching experience 19.6 years. Primary school teachers' average age was 44.7 and teaching experience 20.6 years. The data was collected with a questionnaire. Teachers were asked about their opportunities to select learning materials, principles for choosing materials and the instructional goals included in high quality materials. For comparing teachers' responses Mann-Whitney U-test and Chi-square test were used. Teachers' open-ended answers were analysed by 
content analysis. The goals of high-quality learning materials were divided into three groups according to the classification of learning skills by Hattie et al. (1996), i.e. cognitive, affective and metacognitive skills.

\section{Results and Discussion}

\section{Opportunities to decide on the choice of learning materials}

To answer the first research question, the researchers analysed to what extent pre-school and primary school teachers can decide on the choice of learning materials. The analyses showed that $92.2 \%$ of pre-school teachers and only $8.5 \%$ of primary school teachers had full autonomy over what learning materials they used. $76.6 \%$ of the primary school teachers reported partial possibility to select learning materials and $14.9 \%$ stated that they could not decide what learning materials to use.

\section{Principles for selection of learning materials}

Based on the teachers' open answers four main categories were formed. In the first, "Compliance with the Curriculum," primary school teachers referred more often to modernity and affordability as selection principles, while preschool teachers reported age-appropriateness and integration. Playfulness of learning materials was reported only by pre-school teachers. There is a conflict of opinion between pre-school teachers who value playfulness and subject integration, and primary school teachers who do not consider these principles so important.

The variety of content and tasks in the second category "Content and Assignment Diversity" was mentioned almost equally by pre-school and primary school teachers. Similarly, they mentioned that the curriculum must be diverse. However, pre-school teachers mentioned some principles more often than primary school teachers: developing creativity, individualisation and an interest to learn. Previous studies have emphasised the importance of diversity of learning materials, easy differentiation of teaching (Reints \& Wilkens, 2019), and individual approach (Czeglédy \& Kovács, 2008). These principles were also mentioned in this research. Only a few respondents mentioned creativity as an important principle.

In the third category "Clarity and Comprehensibility of Content and Tasks" three of the four principles were mentioned more often by pre-school teachers than by primary school teachers. The comprehensibility of the structure of learning materials received more support from the primary school teachers. Earlier studies have shown that the content must be clear (Ho \& Hsu, 2011) 
and the instructions understood by the pupils (Howard \& Major, 2004). Only pre-school teachers mentioned the importance of authentic illustrations.

The fourth category was "External Factors". Compared to other categories, these principles were the least mentioned. Previously, it has been found that the availability of additional materials (e.g. a workbook, etc.) is important for the integrity of learning materials (Czeglédy \& Kovács, 2008). Other external factors (e.g. price, additional materials, previous experience) were mentioned more by primary than pre-school teachers, who, on the other hand, pointed out the attractiveness of learning materials.

\section{Teachers' evaluations about the goals of learning materials}

To answer the third research question, teachers had to select the goals of highquality learning materials. Among the cognitive, affective and metacognitive goals there was a significant difference between the two groups regarding the metacognitive goals. The primary school teachers have chosen metacognitive goals significantly more than pre-school teachers $(\mathrm{p}<.01)$. Therefore, the importance of developing children's metacognitive skills should be given greater importance in the training of pre-school teachers.

In conclusion, as primary school teachers had limited opportunities to select learning materials, it would be necessary to raise awareness of school leaders to trust teachers as experts in choosing such materials. Among pre-school and primary school teachers only one-fifth or fewer respondents mentioned principles other than age-appropriateness. We must consider that in the questionnaire teachers had the opportunity to name only the three most important principles of the choice of study materials. So, it cannot be concluded that they do not follow other principles they did not indicate now. Pre-school teachers should be encouraged to develop metacognitive skills through learning materials.

Keywords: learning material, pre-school and primary teachers, principles and goals of learning materials 